\title{
The use of water attributes in oral or written poetry characters
}

\author{
Sharipova Laylo Frunzeevna \\ Doktor of philological science, docent of Bukhara State University. Uzbekistan
}

\begin{abstract}
In article was written about the water attributes as river and rain found in mythology that has been transferred to oral poetry, from folklore to written literature. The metamorphosis of water and the poetic functions of them in poetry were investigated.

Key words: mythology, folklore, written poetry, poetics, stylistic, poetic formula, song, river image, rain image.
\end{abstract}

The Uzbek Literature has published a number of studies and researches in the field of folklore and literature, which is the problem of the transformation of folklore images into written literature. In scientific works of "H.Olimjon asarlarida folklor traditsiyalari"(Folklore traditions in H.Olimjon's works) by S.Mirzaev [5.258-274.], N.Mallaev's "H.Olimjon asarlarida folklor traditsiyalari”(Alisher Navoi and folk art) [9.149-152], S.Mamajonov's "Folklordan o'rganaylik"(Let's learn from folklore) [10.210-225], O.Sobirov's book "Sarchashma adib ijodida”(“Sarchashma (the source) in writer's works) [14.60], M.Amilova's “O`zbek sovet adabiyotida folklor an'analari”(The folklore traditions in the Uzbek Soviet Literature) [4.100] were written the influence of folklore images on written literature. But this process has not been studied yet.

The study of the phenomenon of mythology in the process of styling folklore images also enhances the opportunity to explore the role of folklore in poetry. The majority of people in the world originated mythology, and then the motif of the mythology, the image of the world, the reality, and the origin of the oral folk tales. At the same time, folklore was instrumental in the creation of written literature. The continuing influence of folklore on written literature, including poetry, is yet another proof that the study of this process is essential both for folklore and literature.

In "Saddi Iskandariy", Alexander asked Socrates why he did not cover the whole earth with water. Socrates emphasizes this wisdom divinity. The water always flows from the top to the bottom, tells the truth that the water of the universe is low. According to Socrates, the world should actually be a water mirror. See the following conclusion of Navai:

Tutulmoq kerak edi yer suv bila,

Hamul navkim aks ko`zgu bila.

Vale khalqkim haqqa oson edi,

G`araz ofarinishdin inson edi.

Anga jilvagoh ochdi qudrat bila,

Bu ma’niga yo `q daxl hikmat bila.

Muni bil hakimi azal hikmati,

Ki topmas bulardin xalal hikmati [3.454.].

Water flowing from high to low, its glory is expressed in the East, first of all in "Avesto". This analogy is given in several places, including the 38th chapter of the Yasna: "Finally, we welcome the 
waters. We praise the subterranean, sedate, and good-natured natural waters. "O waters! You are wellbuilt. You can clean the shroud and clean the two worlds. We will honor you [2.161]." The water is glorified because it purifies everything. At the same time, the water has many functions. That is why the poetic aspects are diverse.

The study of the phenomenon of mythology by folklore and the folklore poetic creativity has also enhanced the opportunity to explore the role of folklore in poetry. Water, drops, dew, rain, hail, snow, steam, fountains, wells, springs, rocks, arches, lakes, rivers, seas, and oceans are the attributes of water. It is evident that the water is diverse according to its place of metamorphosis. The same distinctions are the key to their image conversion.

Saxovat momosi tog`ning ko`ksidan

Ko`pirib, hayqirib suti to`kilmish.

Zarrasi sochilgan muzlar ustida

Shoshqaloq g’unchalar choki so`kilmish,

Demak, bahor keldi.

If you read Zulfiya's poems, you will realize that the author of the lines is an Uzbek woman. The above rows were derived from the phrase "Demak bahor keldi" (So spring came) and referred to the mountain grandma of generosity. In the spring, the flow of water from the mountain is described as "shredded milk" from the breast of the mountain, which is a rare occurrence. Describing the mountain as a momo (grandma) indicates that the figures refer to women. The brush is regarded as a "hustle" of a woman as she discovers that the bubbles "open up on bubbles of frozen ice" - that is, melted under icefloating. Because this spring, in the words of the poem, Socrates "spring fall". Zulfiya's poetry reflects women's emotions and thoughts on a high level, which is not found in the creativity of all poets. This is a real woman, a mother.

According to folklorist A.Musakulov, the traditional poetic lines, such as "The Wave ...", "The height ...", "Along the banks of rivers", have become traditional poetic formulas. "According to archaeological imaginations, water has always been a boundary between the worlds". A. Potebnya said that the transition from water (river, sea, aryk (a little river)) was a symbol of marriage in folk art [12.194]. In our case, the water in our body, which holds our world, is also a prosperous and destructive power. While the four elements are interconnected, the water is able to withstand fire, and there is soil and air in it. There are only four elements that can be displaced in water: water - steam - rain - snow ice - hail and so on. This opportunity has taken place in poetry.

Usman Azim wrote in his poem "O'rdadagi ko'prik ustida" (On the bridge over the river) metamorphosis of the water turbulence with great ability to describe his lifetime commitment. The poet remembers as the lyrical hero "When he meets a lady on a bridge over the hill," he recalls his mother to the river running through the rocky shores. The lyric hero imagines his "mother" as he sees the "infinite cloud on the horizon". He remains: "A poet was taken by a poet. He says, "I am a child who knows the power of the song, a self-knowledgeable boy," and "I left my mother, who had been an outcast". The hero imagines his "mother" as he sees the "infinite cloud on the horizon". He recalls: "A poet was taken by a poet. He says, "I am a child who knows the power of the song, a self-knowledgeable boy", and "I left my mother, who had been an outcast". The poet's eyes are poured for youth, not for poetry. It 
seemed to her that she was carrying his knot and knitting water. Usman Azim draws water attributes in the following order, using the art of painting to draw the landscape: bridge - anchor - clouds - hail tears - water collar. These evolutionists seem like the poet's mother. The bridge details have a connection. Actually, "the bridge that connects the two sides of the water in the folk songs draws the meanings of the water marker, the coalescence, the bridge passing towards the marriage and the maternity world [12.194]". "The next poem is like a logical continuing of the poem on the bridge in the river". The poet lives ten days before his autumn. The writer, who wanted to go out wrote:

Sohillar taqdiri - ona-bolalik,

O`rtamizda daryo oqqani-oqqan.

Ona, ketarimda g`uborsiz kun ham

Yuzimizga yomg`ir yog`gani-yog`gan... [15.106.]

It is evident that in the poet's poem river describes separation, but this separation is the separation of the mother and the child, not the ones who are loved by the verbal lyric.

Daryolar adashdi yurar yo lidan,

Yomg irlar adashdi, qorlar adashdi.

O`rdak bilan g`ozi uchdi ko`lidan,

Taqdiri chalkashib yorlar adashdi [20.11.].

These lines, written in 1989, are derived from poetry written about anarchism in our people. O. Hodjieva's skill is that the series of cross-lines linking the river, rain, snow poetic characters in a sequence of water attributes. Ducks and gooseberries are related to watercourse as aquatic creatures and their absence is a sign of evil. It is natural and vice versa that there are water animals in clean and pure water. It is clear that the misguidance leads to separation. The four lines in the line are logically linked, yet both content and composition are integral. The same can be said in the poet's poem "Iltijo(Prey)".

Among the poetic characters such as snow, rain, and lamb, there is a river, and one of the water attributes which is widely used in our oral and written poetry.

"Daryo - toshqin", "Uzgancha", "Hay, yor, yor, yor, yorammo", "Jambilhon", "Aman, omon, omon-ey", "Daryodan oqib kelar", "Naylay", in the folk songs, the river image depicts the separation:

Seni - unda, meni - bunda yaratdi, yor-a,

Oramizda oqar daryo yaratdi.

Oqar daryo ekan - oqdi-yu ketdi,

Bevafo yor ekan - tashladi-ketdi [18.32.].

There are also traditional motifs related to the river, in this songbook "Yor-Yorlar" 2-6-12-18-2324-25. The population was so poetic that it meant the trap of the river, its flow, the division of land into two, and the flowing of two coasts. For this reason, he is concerned about the opposite of the house of his lover and that the flow of river water is an act of two loved youth relationship, with the abandonment of the abyss.

Daryolarning ul yuzida shaftolizor-ey,

Shaftolizor taglarida qizlar bozor-ey.

Otalari sotar bo `lsa - biz xaridor-ey,

Onalari sotmas bo`lsa - bizlar bezor-ey! [18.98.] 
The elbows of the rivers are the place where love is to be drawn. Why is it pebbles? It is not gullet, apricot, or nectar. Was this fruit not used for lyric vazn (Arabic literary form) only?! We thought that the peaches were not also made of their beauty but peach, rhubarb, nuts, figs, and flowers have angels. Hence, the brick is a market for paramour girls. It is evident that the folk songs are poetic representing the occurrence of rivalry, love, marriage, separation, and adultery. This is a picture of a popular song.

In the case of modern poetry, we can say that the river:

1. It is a beautiful and powerful compilation of the essay. It is enough to remember the poem of Mirmemir's “Amu qirg`oqlari” (Amu shores):

Oq yolli asov tulpor,

Bebosh va tentak oqin.

Qumloq sahro erkasi,

Va daryolar serkasi [11.94.].

2. Creating quality. It is used as something similar in Tashbih (comparison). "River Man", "Mercury River", "Ilhomi River", "River of Hearts":

Shoirlar, muhabbat yalovchilari,

Mayli, daryo bo`lsin mehr ila shafqat [6.171.].

3. Released to an image level. We will give examples later.

There are some kinds of works in which the river is used in the above three cases. Sirojiddin Sayyid's poem "To polondaryo bilan xayrlashuv" (The Farewell to The Nightingale) has received such a brilliant concept of "river".

In our modern poetry, it is scientifically important to observe the poetic meaning of the river, and to find out about the similarities and differences in two literatures in this regard. Modern poetry has interpreted the river image as devoid of folk songs, frivolous love and happiness, and interpreted dozens of new meanings:

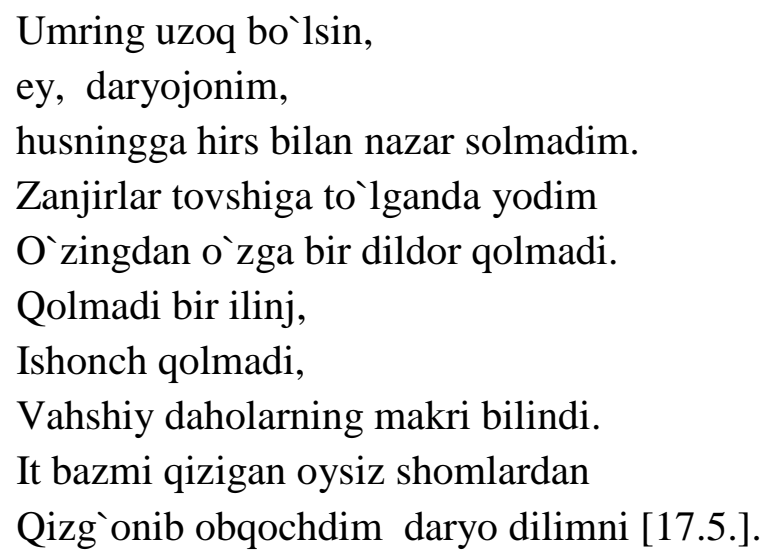

The above clauses are from Shavkat Rahman's poem "Yorilgan harakat bayoni" (Cracked Movement Statement). The river image in poetry is significant because of the multifaceted nature. For that reason, each poem had the ability to interpret the river image. Someone thinks that the image of the 
people and someone else thinks as freedom image. The combination of "My river" motivates the poet to think of his own language. The following lines make the poet even more surprised, and call for a deeper look. "Daryodil (Riverheart)" is used as a coherent term, and width, as well as the meaning of serpentine:

Daryodil samoga dilimni berdim.

Umring uzoq bo`lsin,

Ey daryojonim.

In the last lines you can think about poetry, manuscripts, and poems. The river, where the marshes are flooded by mountains, may be the symbol of fair:

Aytgil, ey daryojon,

Bormidi zulm?

Tog`lar silsilasin buzvordi nola:

"Gullarning bargini yemagan gulim,

Bulbullar qonini ichmagan bolam".

Shavkat Rahman was a qualified poet, a poet well-versed in the power of the hand, a great poet who "didn't eat the flower leaves" and "did not drink the blood of the nightmare". The river image created a unique opportunity for the poet to express his thoughts.

Sirojiddin Sayyid raised the river to an image in the epic "To'palondaryo bilan xayrlashuv" (Farewell to the Topolondaryo (Disturbed river)). Through the river image, he was able to convey his innermost feelings and abilities in his mind. River image in his poetry has a lot of characters:

1. In the "Tavallo" section of his poem, the river is a metaphorical expression of life, which, in essence, is a sublime expression of the Creator's manifestation, agility:

Odamlar ko`rdim men - xasdek benishon,

Odamlar - zamin-u zamondan ayro.

Hayot daryosidan chetroqda qolsam,

O`zing qo`shib qo`ygin meni, jon daryo.

Endi tiriklikning o`zanlarida

Tug`yonlar jonimga kirgaydir oro.

Dardlarning g`ov bosgan to`g`onlarida

O`zing tug`yon bergil menga, jon daryo! [13.180.]

2. "Mullo Oqilning betob yotgan Vahob shoir bilan suhbati"(Mullo Akil's Interview with an ill Vahhab poet) tells us that life is like a river, and the poet portrays the image of the river as weak. This is not ordinary insignificance; the symbol of the historical weakness of the great nation, which has given tens and hundreds of glories to the civilization of the world, is the river. The image of the Motherland is a river that could not save their children who were stoned on the neck and buried their corpses. While depicting the tragedy of the 1930s, the poet appealed to the prose in poetry like folk epics. He uses the 
folklore-specific image method as he expresses his thoughts through the Saj: "I had two sons, mulla. She was not on the line, and the girls were hard on them. My face was full of dust. My sons were mountains. Oh, the world! What have you done? My heart is tilt! My firstborn was nineteen years old, Mulla! They besieged his neck and blew him to the river. They broke my tears. Oh, the world! "The river is the innocent guilty of the poet's two sons, now the river has become his sons, and the poet's sons have become river. According to the poet Vahhab, Topolandarya was 19 years old and without any babies. As Mulla Akil says the river is a symbol of immortality. Sirojiddin Sayyid, in his prosaic narrative, gave folk tales in a special way, and this method of image serves to strengthen the peoples of the world and nationality. "I tell you, we have more or less grave sins. What do you say to people? What you say to people? People ... What you say?"," Let no one get caught as people, mulla (a religious person)! "An orphan is without parent who is abandoned and abused in someone's hands. Self-esteem Motherland's dependence means that a whole nation is not free and has not freedom. The poem that follows after this prose divide is the same as in folk epics:

O`z yurtin ko`ksiga o`q

Otganlarni ko’rganman.

Eldan chiqib, elini

Sotganlarni ko`rganman.

Qolsa mendan So`z qolar,

Donday sochib yurganman.

Buyuk xalq birlan buyuk

Muxtojlikni ko’rganman [13.182.].

Here Sirojiddin Said describes the greatest need that the great nation has seen in the support of the river image. If our people were not convinced of faith, with soul or patience we would not be handicapped. This great need could not sweep our nation out of history. In 1930s, the slaughtered people became dust. In their chest, as the poet says, "the times are going on".

3. In the part of "Memoirs" of the poem depicts the tragedy of the Uzbeks in the Second World War. Even when they see that their children die of starvation, the hard-hearted nation that has eaten the last bread with the strangers is likened to a river. The essence of a poem becomes evident. The story of Uzbekistan's relentless fate from the 30s of the 20th century to the desert is a river polarizing.

4. The part "Child" of the poem began with the phrase, "You came to the river coast" that can be seen as referring to the children of the two rivers. The poet describes this child as the hero Farkhad, who has been created by Navoi as a symbol of maturity, describing it as "the cradle of the hands shook winds", "it decorated their sleep with herbs" and "dropped his early muscles in the morning". The poet says to today's Farkhad followings:

Bularning barchasi Vatandir, Vatan!

Tovoning o`pajak har bir tosh - Vatan.

Sen hali bilmaysan - yangi ayvonning

Shiftini tanlagan qaldirg`och - Vatan [13.192-193.]. 
The poet admits to the hero that one day he will meet the Motherland when he says, "Your tongue is as smooth as the water", "Eagles are flying over the mountain from your heart", and "The highest peaks of the heart". These figures reflect the image of the Homeland, but at the same time there is a portrait of patriot young man.

Poem has a tile, a garden, a mountain, and a dam around the character of water. The writer argues that he did not deny names "Nihondara" and "Hayronbog" in the poem. There are such strings in our homeland, full of mystery. They have covered the secrets of our Homeland. These secrets were amazed by the gardens of the rivers. Those who have fallen in love with our native land have cut down trees in these "flies" and have lost all our gardens. In fact, the trees on the banks of the rivers carry both meaning and metaphorical meaning to the reader, who can propound it. The poet describes the dam that has been built in Nihondara for the readers:

To`g`on, asrlarim qum bo`lib oqdi,

Bobolarim chopdi:

- Jon dashtim, uyg`on!

Qurg`oqchil zamonlar, kamchil davronlar,

Qatma-qat armonlar hammasi - to`g`on [13.191.].

As the poet deepens the essence of the river through the "dam" detail, he imposes a negative and positive imprint on the dam. Such things as "lies, foul language, laughter, words"; "The hypocritical, selfish nets", "Those who are looking for benefits from the dormitory", "All those who have created slogans from the sacred words and who keep their conscience" are a dam for the sake of Motherland" , says the poet. Through humanity, with the words of the human soul, the perverted path lies in the metamorphic image of the river:

Gohi tinch daryoday hayron ketdim men,

O`ng tomonda - yolg`on,

Chap yonda - yolg`on.

Insoniy bir mehr, bir kaft, bir kalom

Bilan siz yolg`onga bo`ldingiz to`g`on.

Mening umrim nadir -

Toshqindir, seldir,

Oqquvchi ko`ngillar ko`klami tomon.

Yomonga yomondir - kulfatlari bor,

Undan ham betug`yon omonlik yomon [13.191-192.].

The poet describes the ideas of patriotism, humanity, and humanitarianism through the river image, describing it as "peaceful river", "river of life", "eye-flowing river", "soul drainage". This river is needed for "spiritual steppes", and should "hinder man through the pits of dread". The fact that most of our contemporary poetry is that the poet called people to be river. The river's vigor is combined with features such as its constant motion, cleanliness, cleanse the dirt, give life to thirst, and magnify it. The 
poet asked the reader questioning whether a human being could be a river beforehand:

O`zbekiston, tashna yurtim,

Tuproqlaring nurga to`lib

Toshganini ko`rganman men

Daryo bo`lib, daryo bo`lib.

Faqat Amu, Sirdaryomas,

Sohilidan ayrolaring -

Usmon Nosir, Qodiriylar

Sening ulug` daryolaring! [13.202.]

The poetical image of the river can be the symbol of the people. The following lines are based on a poem describing the people and its evolution after saying: "People are the sea, the people are waves, the people are strong" in the poem "Xalq" (People) written by Chulpon:

Daryo-daryo emas, u xalq-ku, axir,

Zaminga shimilib, bug` bo`lib ko`kka-

Tag`in qaytayotgan ul yuksaklikka.

Tag`in yog`ayotgan yomg`ir, qor bo`lib,

Erib, qirg`oqlarga sig`masdan qolgan.

The poet asked the readers questioning whether a human being could be a river beforehand:

Daryomas, xalq-ku bu...

Kelmoqda to 'lib[16.28.].

The victory of Usman Kochkar is that during the 70s and 80s of the last century, the people were able to point to the fact that the patience was overflowing, and that it was flooded with the river image. This was a sign of a struggle on the way to Freedom. It appears that in the poetry, in the second half of the XX century, the Uzbek poetry was transformed into a powerful force that infringed every obstacle of creativity, kindness, majesty and perfection. In a written poem, people are compared to the sea, like the river, in the folk proverbs, in contrast to the water and the people:

Baliq suv bilan tirik,

Odam xalq bilan [19.5.].

The people, before the poets, gave a precedent: "If the people go up it is a river", "Look at the water, look at the people's desires". It is impossible (нима?) without a flow of water to human beings. This is because in rivers such as rivers, rivers, rivers, and oceans, it is impossible to resist water flow. That is the will of the people. Such stories have allowed our poets, like Chulpan and Usman Kochkar, to compare the people to the sea, to the river. In conclusion, our modern poetry has created a poetic image of the river and has discovered new aspects in its folk lyric skills. As a result, the share of the river image has increased: it has become a means of showing the power of the people, along with the expression of separation, visol. The river is both alive and alive; both creative and destructive; has become a vast image in oral and written poetry as an indispensable power that conceals and discloses human secrets. 
In our poetic lesson in our oral poetry one of the images that are rich in colorful poetic edges is rain. As it plays an important role in the development of water, it is thought to be a hail-like phenomenon, with floods, frosts, spring rains, and air-cooling. Yuldash Eshbek uses the word "rain" in his poem“Bahor osmonlari” (The Sky of Spring) in its own meaning (neutral meaning):

Bir ajoyib tong bilan mayin

Qo`shilishib yomg`irlar yog`ar.

Och pistoqi, lojuvard, zaif,

Nurlar seli - zumradlar oqar[8.55.].

In the morning to see these lines, it is necessary to watch the rain when it is dark. The poet will see a light rainbow, luster, and agility of the rain. The poet, who has shown rain as a natural phenomenon, now uses it in a portable sense. Note the poet's wish to untie his voice and put his chest in the rain:

Maysalarning og`ushida jim,

"abadiylik sari adashib"

yuragimga yomg irlar quysin,

Deb tanimni yechib tashlardim,

g iloflarni sindirmoq payti

o`sar yurak ochiq bag`rida!

Butun olam yonib porlaydi

uning shaffof uchqunlarida![8.55.]

According to the poet, because of the rain the heart grew and the chest - the blanket broken. The open heart grows into a transparent spark, and the world is shining. If the heart is a huge flamethrower, when it rains, transparent sparks splurge. With the help of rainfall scenes from the spring sky, the poet brought poetry, which praises freedom, peace, cleanness and poetry:

Ko`zlaridan quyilar sevinch,

Porlar yomg ir aro insonlar.

Mening yurtim osmonini hech

Tark etmaydi abri naysonlar![8.56.]

When it's raining, people are tired of joy, and they are happy. The country where the sky is not abandoned is great. Yuldash Eshbek refers to the fact that his homeland is serfdom. It is a unique poem about the Homeland that has been inspired by the rain.

Abduvali Kutbiddin's "Yomg'ir" (Rain) poem consists of two parts. In the first part there is a falling rain and a love of the soil. The lover, the lover, which he loved, is primarily rainy. The fourth line in all the poems is the same: "Nobody loves me". That is the pain that pains the poet. The heroine wants to become a rainbow.

Qiyofam yomg`irda, u esa menman,

Tag in qayta-qayta ko`rinish berdim.

Tezroq yashiringin, tomchiman, tig`man,

Meni sevmas hech kim [1.55]. 
When will the rain be a line? An unloved person first gets disturbed, and this pain becomes anger, anger, and hatred. As the poet describes this process, it describes the fall of this unloved love into the rain. Only in an irritable state, that is, raindrops can turn into bark. Even though he does not like it, he asks why he loves to hide from his beloved, saying, "No, no, no, I do not care". In the second episode of poetry it is said that the lover, "I was ended, ended, finally", which has become a rain and thrust into the soil, has changed its position and is offended by the wrath of the grass.

It would be correctly stated in the phrase "Who sings and sends a greetings from him, this spring from", and not "from him", "this spring" to him. As the evolution of folklore genres is reflected in various ways, the poet asks rain in part 2 of poetry promotes mint spinning and asks for mintage:

Yalpizim, suyuklim uyigacha bor,

Iloj qil, deraza rohida ko`kar,

Bo`y tarat, dimog`i yonsin, u bilsin,

Mendan bu xabar [8.55.].

Then he wants to see his love's face with becoming a cork. Then he wants to stay on his love's hand with the help of becoming a dove:

Bir soat, ijozat ayla, quvonay,

Don bersa ajabmas kaftida orzum.

Zora men haqimda surib qolsa o`y,

$$
\text { Zum... }
$$

"Zum ... Zum ..." It is natural that the reader would say "one moment". In our opinion, by giving the word "zum" to the word "double", he puts a lot of points, and the vigilant reader has also heard the voice of a pigeon's "zum-zum". The poet hopes to do all of these dreams through a lyrical hero who has evolved into the rain.

It is evident that rivers, rainfall are natural phenomena which considered water attributes in mythology. Over time, folklore, after as a poem of written poetry was performed various poetic tasks. Studying the poetic function of these characters plays an important role in covering the issue of interactions in folklore and written literature.

\section{References:}

1. Abduvali Qutbiddin. Sen va sen uchun. - Toshkent: G`afur G`ulom nomidagi Adabiyot va san'at nashriyoti, 1996. - B.55.

2. Avesto. Tarixiy-adabiy yodgorlik. - Toshkent: G`afur G`ulom nomidagi NMIU, 2015. - 732 b.

3. Alisher Navoiy. Xamsa. Tanlangan asarlar to plami. 10-jildlik. 8-jild. - Toshkent: O`bekiston Matbuot va axborot agentligi G`afur G`ulom nomidagi nashriyot-matbaa ijodiy uyi, 2011. - 712 b.

4. Amilova M. O`zbek sovet adabiyotida folklor an'analari. - Toshkent: Fan, 1990. - 124 b.

5. Doniyorov X., Mirzayev S. So`z san'ati. - Toshkent: O`zdavnashr, 1962. - 316 b.

6. Jamol Kamol. Asr bilan vidolashuv. Saylanma. - Toshkent: Fan, 2007. - 336 b.

7. Zulfiya. Mushoira. Asarlar. Uch jildlikning 2-jildi. - Toshkent: G`afur G’ulom nomidagi Adabiyot va san'at nashriyoti, 1985. - 536 b.

8. Yo'ldosh Eshbek. Mangu masofa. - Toshkent: G`afur G`ulom nomidagi adabiyot va san'at nashriyoti, 1991. - 192 b. 
9. Mallaev N. Alisher Navoiy va xalq ijodiyoti. - Toshkent: G’afur G`ulom nomidagi NMIU, 2015. - 432 b.

10. Mamajonov S. G`afur G`ulom prozasi. - Toshkent: Fan, 1966. - 226 b.

11. Mirtemir. Saylanma. - Toshkent: Ma'naviyat, 2012. - 296 b.

12. Musaqulov A. O’zbek xalq lirikasi. - Toshkent: Fan, 2010. - 308 b.

13. Sirojiddin Sayyid. So`z yo`li. Ikki jildlik tanlangan asarlar. 1-jild. - Toshkent: "Sharq", 2008. - 384 b.

14. Sobirov O. Sarchashma adib ijodida. - Toshkent: Fan, 1975. - 68 b.

15. Usmon Azim. Saylanma. - Toshkent: Sharq NMK, 1995. - 432 b.

16. Usmon Qo`chqor. Og`ir karvon. She'rlar. - Toshkent: G`afur G`ulom nomidagi Adabiyot va san'at nashriyoti, 1991. - 128 b.

17. Shavkat Rahmon. Saylanma. - Toshkent: Sharq NMK, 1997. - 384 b.

18. Shoda-shoda marvarid.O`zbek xalq qo`shiqlari. - Toshkent: Sharq, 2006. - 416 b.

19. O`zbek xalq maqollari. - Toshkent: G`afur G`ulom nomidagi Adabiyot va san'at nashriyoti, 1989. - 512 b.

20. Hojieva O. Panohim: she'rlar va hikoyalar. - Toshkent: Sharq NMK, 1998. - 240 b. 